\title{
Artigo
}

\section{Empresários e financiamento de campanhas na eleição presidencial brasileira de 2014}

\author{
Business and campaign finance in Brazil's 2014 \\ presidential election
}

\section{Wagner Pralon Mancuso}

Professor, Universidade de São Paulo (USP), Escola de Artes, Ciências e Humanidades, Programas de Pós-graduação em Ciência Política e Relações Internacionais, São Paulo, SP, Brasil pralon@usp.br

\section{Rodrigo Rossi Horochovski}

Professor, Universidade Federal do Paraná (UFPR), Programas de Pós-graduação em Ciência Política e Desenvolvimento Territorial Sustentável, Setor Litoral, Matinhos, PR, Brasil rodrigoh33@gmail.com

\section{Neilor Fermino Camargo}

Doutorando em Ciência Política, Universidade Federal do Paraná (UFPR), Professor, Universidade Federal do Paraná (UFPR),

Setor Litoral, Matinhos, PR, Brasil camargon@gmail.com

Resumo: Este artigo analisa o financiamento empresarial de campanhas na eleição presidencial brasileira de 2014. Em primeiro lugar, discute fatores de nível individual e setorial que influenciam a decisão dos empresários de contribuir para campanhas eleitorais. Em segundo lugar, explica a dinâmica do fluxo de receitas eleitorais na eleição estudada. Em terceiro lugar, mostra como o financiamento eleitoral empresarial se distribuiu naquela eleição, mensurando o total investido por empresas e setores econômicos, bem como o grau de dependência 
e dominância das diversas candidaturas em relação às doações feitas pelos diferentes setores da economia brasileira. Por fim, a partir da decisão do Supremo Tribunal Federal que proibiu as doações eleitorais do empresariado, o artigo reflete sobre o futuro do financiamento de campanhas no país e sobre o modo pelo qual as mudanças poderão afetar o comportamento dos partidos políticos e de suas respectivas candidaturas presidenciais.

Palavras-chave: Empresariado; Financiamento de campanha; Partidos políticos; Candidaturas; Eleição presidencial brasileira de 2014.

\begin{abstract}
This article analyzes the entrepreneurial sector as a source of campaign contributions in Brazil's 2014 presidential election. First, it discusses the factors that influence business' decision of giving money to electoral campaigns - both at the individual and sectoral levels. Second, it explains the dynamics of the flow of electoral incomes in the studied election. Third, it presents how business campaign financing was distributed in that election, measuring not only the total amount invested by companies and economic sectors, but also the levels of dependence and dominance shown by all candidates in relation to the donations which came from the different sectors of the Brazilian economy. Finally, taking into account the recent decision of the Brazilian Supreme Court that prohibited campaign donations from business, the article reflects both on the future of the campaign finance in Brazil, and on how these changes can affect the behavior of political parties and their presidential candidates.
\end{abstract}

Keywords: Business; Campaign finance; Political parties; Political candidacies; Brazil's 2014 presidential election.

\title{
Introdução
}

Ao estudar o presidencialismo brasileiro, a ciência política precisa olhar não apenas para as instituições, mas também para os interesses que se constituem e se mobilizam em torno delas. O objetivo deste artigo é contribuir para o enfrentamento desse desafio, analisando a mobilização de interesses empresariais na eleição presidencial de 2014, por meio do financiamento de campanhas.

A primeira realidade que salta à vista de quem estuda a última eleição presidencial brasileira é o predomínio incontrastável do dinheiro de empresários. De fato, quase a totalidade das centenas de milhões de reais que movimentaram aquela eleição veio de empresas. Cabe, então, perguntar: por que doam os empresários? Como seu dinheiro se distribui entre as candidaturas que disputam o voto popular, e o que explica esta distribuição? Que setores econômicos mais se destacam como fonte de recursos? Por que eles se destacam? Em que medida as candidaturas dependem das contribuições emanadas dos diferentes setores? E em que medida as dominam? Que fatores explicam os níveis observados de dependência e dominância? Que cenário se descortina para as campanhas eleitorais no país a partir da decisão do Supremo Tribunal Federal (STF), tomada em setembro de 2015, que vetou o financiamento eleitoral empresarial? 
Essas são as principais questões que estruturam o presente trabalho. Para algumas dessas questões, os dados existentes nos permitem oferecer respostas mais precisas. Em relação a questões mais controvertidas, que ainda não podem ser respondidas com as informações disponíveis e o conhecimento acumulado até o momento, procuramos apresentar algumas reflexões e sugerir uma agenda de pesquisa. Sendo assim, este texto se filia à crescente literatura de ciência política sobre financiamento político no Brasil, e procura colaborar para seu avanço'.

Este artigo está dividido em quatro seções. A primeira seção discute fatores que influenciam a decisão empresarial de doar recursos para campanhas eleitorais e que operam tanto no nível "micro" (ou seja, no plano do empresário individual) quanto no nível "meso" (isto é, no plano do setor econômico em que o empresário atua). A segunda seção explica detalhadamente a dinâmica do fluxo de receitas eleitorais na eleição presidencial de 2014. A terceira seção se debruça sobre o financiamento eleitoral empresarial nessa eleição, dimensionando o total investido por empresas e setores econômicos, bem como o grau de dependência e dominância das diversas candidaturas presidenciais em relação às doações feitas pelos diferentes setores da economia brasileira. A última seção resume os principais achados do artigo e reflete sobre duas questões a partir da decisão do STF que proibiu o financiamento eleitoral empresarial no Brasil. A primeira questão é: de agora em diante, que rumo tomará o financiamento das campanhas eleitorais no pais? E a segunda questão é: como este rumo afetará o comportamento dos partidos e de suas respectivas candidaturas presidenciais? A reflexão é feita em breve diálogo com a tipologia de partidos (de quadros, de massa, "catch-all" e cartelizados) desenvolvida por cientistas políticos tais como Duverger (1970), Kirchheimer (2012) e Katz e Mair (1995, 1996, 2009, 2012).

\section{Olhando para os níveis "micro" e "meso": a empresa, os setores econômicos e a decisão de doar}

Doar ou não doar? Doar quanto? Doar para quem? Toda doação eleitoral empresarial resulta de uma sequência de decisões cruciais tomadas em um contexto no qual o doador possui informações completas sobre alguns elementos e incompletas sobre outros.

1 Um balanço da literatura sobre o tema no Brasil pode ser encontrado em Mancuso (2015). Um balanço da literatura internacional pode ser encontrado em Figueiredo Filho (2009). 
Há leis que regem as doações eleitorais empresariais. Essas leis definem as empresas que podem doar e os limites para as doações permitidas. Em função disso, o doador sabe se sua empresa pode ou não fazer doações e o limite máximo para elas².

Em relação a outros elementos do contexto em que atua, a informação disponível para o doador é mais imperfeita. Em primeiro lugar, ele sabe que doações podem afetar o desempenho eleitoral de um candidato e que, em alguma medida, o efeito das doações aumenta conforme seu volume. Ele não sabe precisar, no entanto, qual será o impacto exato de suas doações sobre o desempenho eleitoral do candidato escolhido, nem como os outros doadores dividirão suas contribuições entre as candidaturas existentes 3 .

Em segundo lugar, o doador tem acesso a pesquisas de intenção de voto. Tais pesquisas contêm estimativas sobre a chance de vitória dos candidatos. As pesquisas podem sugerir que a eleição já está definida em favor de algum candidato, ou então que o resultado da eleição permanece incerto. $O$ doador sabe que a informação oferecida pelas pesquisas de intenção de voto não é perfeita, mas é a melhor informação disponível sobre a eleição a ser realizada, e então tais pesquisas podem afetar seu comportamento. Entretanto, o efeito das pesquisas sobre a decisão de doar é ambíguo. Por exemplo, quando as pesquisas apontam que a eleição já está definida, isso pode estimular o doador a contribuir para a campanha do candidato favorito, para assim poder figurar ao lado do provável vencedor; ou então pode desestimulá-lo a contribuir para aquela campanha, por considerar que sua doação seria desnecessária e, portanto, um desperdício. Por outro lado, a pesquisa pode também estimular o doador a contribuir para o candidato que está atrás nas pesquisas, para tentar "virar o jogo", ou então desestimulá-lo a fazer isso, abandonando o candidato cuja derrota as pesquisas já anteveem. Quando, ao contrário, as pesquisas indicam que o resultado da eleição permanece incerto, o doador pode ser incentivado a concentrar sua contribuição em apenas um candidato, na expectativa de ajudar a balança a pender em favor de seu preferido, ou então pode ser incentivado a repartir sua contribuição entre dois ou mais candidatos, seguindo a estratégia de "dividir as fichas" e maximizar a chance de êxito - isto é, de contribuir para a candidatura vencedora 4 .

2 O instituto "International IDEA" possui um banco de dados sobre a legislação que rege o financiamento eleitoral em 175 países do mundo (INTERNATIONAL IDEA, 2016).

3 Para estudos que avaliam o efeito do financiamento eleitoral sobre o desempenho de candidaturas no Brasil ver, entre outros, Samuels (2001, 2002), Figueiredo Filho (2009), Peixoto (2010), Marcelino (2010), Lemos, Marcelino e Pederiva (2010) e Horochovski et al. (2016).

4 Esforços para avaliar o efeito de pesquisas de intenção de voto sobre o financiamento eleitoral foram feitos por Marcelino (2011) e Silva e Gonçalves (2016). 
No entanto, não são apenas fatores contextuais que influem sobre a doação eleitoral empresarial. Fatores que operam ao nível do ator também são importantes ${ }^{5}$. Uma lista não exaustiva de fatores deste tipo - que não são mutuamente excludentes e que, portanto, em alguma medida, podem operar simultaneamente - é a seguinte:

- Interesses materiais: a doação do empresário pode ser uma recompensa por benefícios materiais recebidos no passado (por exemplo: o candidato ou seu partido já ajudou o empresário a obter ganhos, ou a minorar perdas), ou um investimento motivado pela expectativa de benefícios futuros;

- Convicções ideológicas motivadas por afinidades programáticas;

- Vínculos pessoais primários (parentesco) ou secundários (amizade, pertença a grupos, etc.).

Até aqui a contribuição eleitoral empresarial foi tratada no nível "micro", isto é, no nível do doador que decide com base em elementos que operam nos planos contextual e individual. Mas também é possível tratar das doações pensando no nível "meso", ou seja, setorial. De fato, mantendo-se constantes algumas características das empresas (tais como número de empregados, nível de faturamento, importância de contratos com o poder público para o rendimento obtido, dentre outras), é possível supor que, em alguma medida, empresas semelhantes que atuam em um mesmo setor econômico compartilham expectativas sobre o impacto que diferentes candidaturas exerceriam sobre suas atividades, caso fossem vitoriosas. Sendo assim, é possível supor que empresas semelhantes de um mesmo setor econômico assumem, até certo ponto, comportamento doador similar diante das candidaturas existentes. É com base nessa premissa que, neste artigo, analisamos o comportamento de setores da economia brasileira diante das candidaturas presidenciais de 2014. Como se discutirá mais à frente, novos estudos mais circunstanciados ainda são necessários para compreender melhor os fatores que levaram os diferentes setores econômicos - e, em última instância, as diferentes empresas que os compõem - a se comportarem diante das candidaturas presidenciais da forma que o fizeram. Este estudo representa apenas um passo nessa importante direção.

5 McMenamin $(2009,2012)$ é um autor que investiga as razões que podem levar um empresário a realizar doações eleitorais. 


\section{O fluxo de receitas na campanha eleitoral de 2014}

Para dimensionar a importância das doações empresariais na campanha presidencial de 2014 é preciso, em primeiro lugar, compreender a dinâmica geral do fluxo de receitas eleitorais naquele pleito ${ }^{6}$.

A Figura 1 mostra que três tipos de agentes arrecadaram receitas de campanha: (i) candidatos (isto é, indivíduos que disputaram votos para presidente, vice-presidente, governador, vice-governador, senador, suplente de senador, deputado federal ou deputado estadual), (ii) comitês financeiros (constituídos em nível nacional para presidente ou vice-presidente, e em nível estadual para os demais cargos, havendo também comitês únicos para cargos diferentes disputados na mesma circunscrição eleitoral) e (iii) partidos políticos (direção nacional, estadual ou municipal).

As fontes comuns de receitas para os três agentes foram as seguintes:

- Recursos de pessoas jurídicas: as empresas puderam doar, no máximo, até 2\% de seu faturamento bruto em 2013.

- Recursos de pessoas físicas: indivíduos que não eram candidatos puderam doar, no máximo, até 10\% de seu rendimento bruto em 2013.

- Comercialização de bens e realização de eventos.

- Rendimentos de aplicações financeiras realizadas com as doações eleitorais recebidas.

Além disso, os candidatos puderam fazer autodoações com recursos próprios, até o valor máximo de gastos estabelecido por seus partidos para o cargo em disputa. Por fim, os partidos puderam utilizar recursos procedentes do Fundo Partidário.

Candidatos, comitês e partidos puderam repassar entre si os recursos que arrecadaram. Entretanto, ao fazerem tais repasses, precisaram declarar a identidade dos doadores originários. Isto é, se o comitê financeiro da candidatura $X$ arrecadou 10 milhões de

6 A eleição de 2014 foi regida pela Lei No. 9.504/97 (BRASIL, 1997), com modificações introduzidas pelas Leis No.11.300/06 (BRASIL, 2006), 12.034/09 (BRASIL, 2009) e 12.891/13 (BRASIL, 2013).

7 A principal fonte de recursos do Fundo Partidário é uma dotação anual do orçamento da União, em valor igual ou superior ao número de eleitores inscritos em 31 de dezembro do ano anterior ao da proposta orçamentária, multiplicado por R\$ 0,35, em valores de agosto de 1995, corrigidos pelo Índice Geral de Preços - Disponibilidade Interna (IGP-DI), calculado pelo Instituto Brasileiro de Economia da Fundação Getúlio Vargas (IBRE/FGV). O Fundo também pode receber outros recursos destinados por lei, doações de pessoas físicas e jurídicas, e multas e penalidades eleitorais. É distribuído assim: (i) 5\% igualmente a todos os partidos e (ii) 95\% na proporção dos votos obtidos na última eleição para a Câmara dos Deputados. Os recursos podem ser aplicados em campanhas eleitorais e também em outros fins, tais como manutenção dos partidos, propaganda doutrinária e política, criação e manutenção de institutos partidários e criação e manutenção de programas de promoção da participação política feminina. 


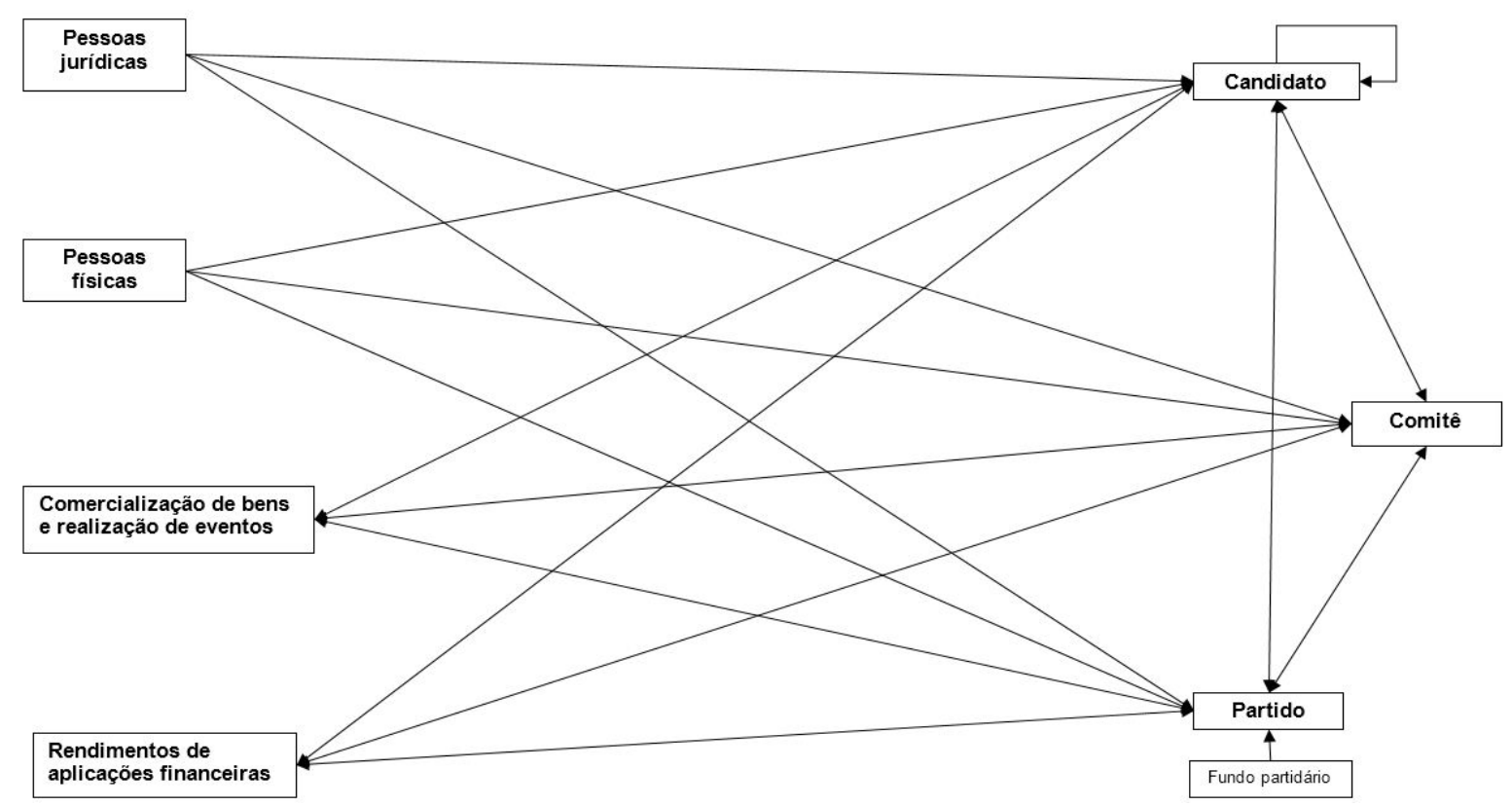

Figura 1. Fluxo de receitas eleitorais na campanha de 2014.

reais, e deste montante repassou cinco milhões de reais para a conta do candidato $X$, então teve de declarar o(s) doador(es) originário(s) da quantia repassada. Esta medida, adotada pela primeira vez na eleição de 2014, visou a combater doações "ocultas", por meio das quais o vínculo entre o doador original e o destinatário final era dissimulado pelo uso de intermediações feitas por outros agentes.

Neste artigo focalizamos exclusivamente as receitas formalmente declaradas à justiça eleitoral em 2014 pelos candidatos à presidência da república, bem como pelos comitês financeiros nacionais para presidente da república. Os repasses feitos entre esses dois tipos de agentes foram descontados, para evitar múltipla contagem dos mesmos recursos. Os valores apresentados na próxima seção podem não corresponder à totalidade dos recursos efetivamente disponíveis para as campanhas, pois (i) as campanhas presidenciais podem terminar com dívidas (o que significa que gastaram mais do que arrecadaram), (ii) outros agentes arrecadadores tais como diretórios partidários, outros candidatos e outros comitês podem realizar despesas diretas que beneficiem as campanhas presidenciais, embora não figurem nas prestações de contas como repasses, e (iii) pode haver receitas subdeclaradas ou não declaradas - o famoso "caixa 2", que por sua própria natureza é impossível de medir, e que usualmente só vem à tona mediante investigações da polícia ou do ministério público. Apesar dessas limitações, o "caixa 1" (ou seja, a receita oficialmente declarada) existe, é vultoso e cresce a cada eleição, merecendo ser estudado. 


\section{Recursos empresariais na campanha presidencial de 2014}

O dinheiro de empresários sustentou a eleição presidencial brasileira de 2014. Em conjunto, as 11 candidaturas à chefia do executivo federal receberam cerca de 650 milhões de reais ${ }^{8}$. Desse montante, nada menos que 610,5 milhões de reais - ou seja, 93,9\% do total - vieram de empresas, seja mediante doações diretas, seja por meio de repasses com doadores originários declarados. Portanto, todas as demais fontes de receitas admitidas explicaram apenas 6,1\% dos recursos recebidos pelas campanhas.

A distribuição das receitas eleitorais foi extremamente assimétrica na última eleição para a presidência do Brasil. A Tabela 1 mostra que, juntas, as duas candidaturas que foram ao segundo turno - Dilma Rousseff (PT) e Aécio Neves (PSDB) - amealharam nada menos que 89,3\% do total de recursos investidos e 90,5\% das doações empresariais. Se a estas for acrescentada a candidatura de Marina Silva (PSB), terceira colocada no primeiro turno, os montantes chegam a 98,9\% do total e 99,7\% das contribuições empresariais 9 . Nas três candidaturas mais competitivas, a dependência em relação ao dinheiro de empresas foi elevadíssima: respectivamente, 95,9\%, 94,1\% e 90,2\% ${ }^{10}$.

As outras candidaturas tiveram de dividir 1,1\% das receitas de campanha e 0,3\% das contribuições empresariais. Embora tenham recebido poucos recursos em termos absolutos, a dependência do dinheiro empresarial se manteve em patamares altos entre as candidaturas menores mais próximas da direita no espectro ideológico: 72,4\% no caso de Pastor Everaldo (PSC), 80,6\% no caso de Levy Fidélix (PRTB) e 90,3\% no caso de Eymael (PSDC). O quadro foi diferente no caso da candidatura de centro de Eduardo Jorge (PV), que declarou não ter recebido nenhum recurso empresarial, e das quatro candidaturas menores ligadas à esquerda: Luciana Genro (PSOL, 13,9\%), José Maria

8 As receitas foram registradas pelos candidatos e comitês entre 01/08/2014 e 24/11/2014. Os valores mencionados no artigo constam nas planilhas disponibilizadas pela Justiça Eleitoral e não foram corrigidos pela inflação acumulada entre o ato da doação e o momento da redação deste trabalho.

As planilhas podem ser obtidas no Repositório de Dados Eleitorais, do Tribunal Superior Eleitoral (TSE) (BRASIL, 2016). As bases de dados utilizadas no texto podem ser solicitadas aos autores por e-mail.

9 Marina Silva era candidata a vice-presidenta na chapa do PSB, encabeçada por Eduardo Campos. Após o acidente de avião que vitimou Campos em plena campanha eleitoral, Silva tornou-se a cabeça da chapa. Neste trabalho, as doações feitas à candidatura e ao comitê de Campos foram somadas às contribuições destinadas à candidatura e ao comitê de Marina. Como mencionado anteriormente, os repasses entre esses agentes foram descontados para evitar múltipla contagem dos mesmos recursos.

10 No primeiro turno de 2014, Dilma Rousseff obteve 41,59\% dos votos válidos, enquanto Aécio Neves alcançou 33,55\% e Marina Silva recebeu 21,32\%. A quarta colocada, Luciana Genro, amealhou apenas 1,55\% dos votos válidos. Todos os outros candidatos receberam menos que $1 \%$ dos votos. 
Tabela 1. Receita das candidaturas presidenciais em 2014 - total e vinda de empresas (em R\$).

\begin{tabular}{lrrrrc}
\hline \multicolumn{1}{c}{ Candidaturas } & \multicolumn{1}{c}{ Total $(\mathbf{A})$} & \multicolumn{1}{c}{ Empresas $(\mathbf{B})$} & \multicolumn{1}{c}{ (B/A*100) } \\
\hline Dilma Rousseff & $350.993 .401,70$ & 54,0 & $336.492 .850,35$ & 55,1 & 95,9 \\
\hline Aécio Neves & $229.302 .063,28$ & 35,3 & $215.845 .731,53$ & 35,4 & 94,1 \\
\hline Eduardo Campos/Marina & $62.494 .677,40$ & 9,6 & $56.399 .084,76$ & 9,2 & 90,2 \\
\hline Eduardo Jorge & $4.389 .318,59$ & 0,7 & - & - & - \\
\hline Pastor Everaldo & $1.433 .485,40$ & 0,2 & $1.038 .385,40$ & 0,2 & 72,4 \\
\hline Eymael & $411.881,31$ & 0,1 & $371.995,35$ & 0,1 & 90,3 \\
\hline Luciana Genro & $401.518,87$ & 0,1 & $56.000,00$ & 0,0 & 13,9 \\
\hline Levy Fidélix & $365.832,44$ & 0,1 & $295.000,00$ & 0,0 & 80,6 \\
\hline José Maria & $171.676,75$ & 0,0 & $5.608,66$ & 0,0 & 3,3 \\
\hline Mauro lasi & $60.554,69$ & 0,0 & - & - & - \\
\hline Rui Pimenta & $10.616,66$ & 0,0 & - & - & - \\
\hline TOTAL & $\mathbf{6 5 0 . 0 3 5 . 0 2 7 , 0 9}$ & $\mathbf{1 0 0 , 0}$ & $\mathbf{6 1 0 . 5 0 4 . 6 5 6 , 0 5}$ & $\mathbf{1 0 0 , 0}$ & $\mathbf{9 3 , 9}$ \\
\hline
\end{tabular}

Fonte: Dados do TSE (BRASIL, 2016) organizados pelos autores.

(PSTU, 3,3\%), Mauro lasi (PCB) e Rui Pimenta (PCO) - sendo que os dois últimos também declararam não ter contado com nenhuma doação de empresas ${ }^{11}$.

Em síntese, os dados da Tabela 1 apontam que dois aspectos diferentes das candidaturas presidenciais de 2014 - competitividade e ideologia - interagiram de forma específica para afetar o volume de financiamento empresarial disponível, bem como a dependência em relação a ele. No caso das candidaturas mais competitivas, todas elas receberam financiamento empresarial farto e mostraram-se altamente dependentes em relação a este tipo de financiamento - tanto a candidatura do PT, ideologicamente mais à esquerda, quanto as candidaturas do PSDB e do PSB, ideologicamente menos próximas deste polo ideológico. Já no caso das candidaturas menos competitivas, o volume de financiamento empresarial destinado a elas foi pequeno, mas a dependência em relação a este tipo de financiamento variou conforme a ideologia: as candidaturas mais à direita mostraram-se fortemente dependentes do financiamento empresarial, ao contrário do que se observou entre as candidaturas mais à esquerda e ao centro. Em outras palavras, num cenário de disputa política acirrada e movida essencialmente a financiamento empresarial, doadores interessados e candidatos competitivos comportaram-se de forma pragmática, buscando apoio mútuo. O efeito do elemento ideológico sobre as contribuições empresariais somente se fez sentir num contexto diverso, marcado por candidaturas pouco competitivas e financiadores menos interessados ${ }^{12}$.

11 A classificação das candidaturas no espectro ideológico esquerda-direta é de responsabilidade dos autores, com base na literatura sobre o tema, coligida em Tarouco e Madeira (2013).

12 Para trabalhos que analisam o efeito da ideologia do partido sobre o financiamento eleitoral recebido por suas candidaturas, ver, dentre outros, Samuels (2001), Speck (2011), Horochovski et al. (2015), Mancuso e Speck (2015a), Mancuso et al. (2016). 
Tabela 2. Doações eleitorais empresariais e Valor Adicionado Bruto (VAB) em 2014, por seção da Classificação Nacional de Atividades Econômicas (CNAE).

\begin{tabular}{|c|c|c|c|}
\hline Seção CNAE & Doações & \% doações & VAB 2014 \\
\hline Agricultura, Pecuária, Produção Florestal, Pesca e Aquicultura & $423.200,00$ & 0,1 & 5,0 \\
\hline Indústria & 435.744.647,94 & 71,4 & 23,8 \\
\hline Indústrias Extrativas & 19.003.175,80 & 3,1 & 3,7 \\
\hline Indústrias de Transformação & $247.924 .784,97$ & 40,6 & 12,0 \\
\hline Eletricidade e Gás & $5.680 .000,00$ & 0,9 & 1,1 \\
\hline $\begin{array}{l}\text { Água, Esgoto, Atividades de Gestão de Resíduos e } \\
\text { Descontaminação }\end{array}$ & $5.705 .009,03$ & 0,9 & 0,8 \\
\hline Construção & $157.431 .678,14$ & 25,8 & 6,2 \\
\hline Serviços & $174.336 .808,11$ & 28,5 & 71,2 \\
\hline $\begin{array}{l}\text { Comércio; Reparação de Veículos Automotores e } \\
\text { Motocicletas }\end{array}$ & $35.682 .064,26$ & 5,8 & 13,6 \\
\hline Transporte, Armazenagem e Correio & $5.707 .930,00$ & 0,9 & 4,6 \\
\hline Alojamento e Alimentação & $505.000,00$ & 0,1 & 2,5 \\
\hline Informação e Comunicação & 2.327.971,90 & 0,4 & 3,4 \\
\hline Atividades Financeiras, de Seguros e Serviços Relacionados & $85.221 .998,75$ & 14,0 & 6,4 \\
\hline Atividades Imobiliárias & $2.215 .000,00$ & 0,4 & 9,3 \\
\hline Atividades Profissionais, Científicas e Técnicas & $7.628 .836,98$ & 1,2 & 3,9 \\
\hline Atividades Administrativas e Serviços Complementares & $17.530 .619,74$ & 2,9 & 4,1 \\
\hline Administração Pública, Defesa e Seguridade Social & - & - & 9,5 \\
\hline Educação & $2.753 .000,00$ & 0,4 & 6,0 \\
\hline Saúde Humana e Serviços Sociais & $5.950 .000,00$ & 1,0 & 4,7 \\
\hline Artes, Cultura, Esporte e Recreação & $54.200,00$ & 0,0 & 0,4 \\
\hline Outras Atividades e Serviços & $8.760 .186,48$ & 1,4 & 1,4 \\
\hline Serviços Domésticos & - & - & 1,2 \\
\hline $\begin{array}{l}\text { Organismos Internacionais e Outras Instituições } \\
\text { Extraterritoriais }\end{array}$ & - & - & - \\
\hline TOTAL & $610.504 .656,05$ & 100,0 & 100,0 \\
\hline
\end{tabular}

Fonte: Dados do TSE (BRASIL, 2016) e do IBGE (2016), organizados pelos autores.

A Tabela 2 mostra que houve grande variação entre os setores econômicos quanto às doações para a eleição presidencial de 2014, e que esta variação não acompanhou o peso relativo dos setores na economia brasileira naquele ano ${ }^{13}$.

A indústria foi o setor que se destacou como principal doador, sendo responsável por $71,4 \%$ das contribuições de campanha, embora tenha participado com 23,8\% do valor adicionado bruto (VAB) da economia nacional em 2014 ${ }^{14}$. Um quadro praticamente

13 Para elaborar a Tabela 2, consideramos o número do Cadastro Nacional da Pessoa Jurídica (CNPJ) de cada empresa que fez doações diretas ou que figura como doadora originária de valores repassados por candidatos, comitês e partidos. Os dados disponibilizados pela justiça eleitoral brasileira identificam a subclasse da CNAE das empresas doadoras. A partir daí chegamos à seção da CNAE a que essas empresas pertencem. As doações não foram agregadas por grupo empresarial a que os CNPJs estão eventualmente ligados. Tal agregação seria muito desejável, mas os dados disponíveis não permitem fazer essa totalização.

14 Valor adicionado bruto é a diferença entre o valor bruto da produção de uma atividade econômica e o consumo intermediário absorvido por essa atividade. Trata-se, portanto, da contribuição ao PIB proporcionada pelas diferentes atividades econômicas (IBGE, 2016, p. 66). A informação sobre o VAB das atividades econômicas no Brasil em 2014 foi obtida na Tabela 13.3 do mesmo documento. 
invertido aconteceu com o setor de serviços, que respondeu por 28,5\% das doações e 71,2\% do VAB. O setor de agricultura, pecuária, produção florestal, pesca e aquicultura ofereceu apenas 0,1\% do total de doações, tendo gerado 5,0\% do VAB.

Dentro do setor industrial, as atividades que mais se destacaram como doadoras foram, respectivamente, a indústria de transformação, que respondeu por 40,6\% das contribuições empresariais, e a indústria da construção, que ofertou 25,8\% do total de contribuições. No setor de serviços, destacaram-se as atividades financeiras, de seguros e serviços relacionados, com 14,0\% das doações. Juntas, as três atividades foram responsáveis por 80,4\% dos recursos empresariais injetados nas campanhas presidenciais em 2014. Para efeito de comparação, essas atividades participaram com 24,6\% do VAB na economia brasileira no mesmo ano.

Por que alguns setores e atividades econômicas destacaram-se como doadores para as eleições presidenciais, sendo responsáveis por um montante de doações que é desproporcional à sua importância para a economia brasileira? A literatura sobre o tema ainda é escassa. Um dos autores que enfrentou a questão foi Samuels (2001). Ao estudar as eleições brasileiras de 1994 e 1998, este autor notou que, já naquela época, a maioria das contribuições eleitorais provinha do segmento financeiro, da indústria pesada (por exemplo: siderurgia e petroquímica) e da construção, sendo que finanças e indústria pesada destacavam-se então como as principais doadoras para os candidatos a presidente.

A explicação oferecida por Samuels para o resultado observado é que tais setores seriam mais expostos à intervenção ou influência do governo. Embora esta explicação aponte um caminho pertinente a ser explorado, ela ainda não é, a nosso ver, muito precisa ou completa. É imprecisa porque os conceitos de intervenção e influência não foram claramente definidos, e os setores e atividades econômicos não foram sistematicamente comparados quando ao grau de intervenção ou influência que sofrem do governo. É incompleta porque, não obstante a possível importância do grau de intervenção ou influência governamental sobre o setor, outros elementos também podem ser relevantes para o fenômeno estudado, tais como a estrutura dos próprios setores empresariais (número e porte das empresas que os compõem, grau de concentração da atividade econômica etc.) ou ainda fatores operantes no nível da empresa, como a quantidade e o valor de contratos com o governo. Compreender adequadamente os determinantes das doações eleitorais empresariais, enquanto elas foram admitidas, persiste como desafio para os cientistas políticos brasileiros. 
Depois que as decisões de todos os doadores empresariais são tomadas, dois índices importantes podem ser mensurados: a dependência e a dominância das candidaturas em relação às contribuições de cada doador e do setor econômico a que este pertence. A dependência indica em que medida determinada candidatura precisa das doações de um empresário ou de seu setor. Em outras palavras, a dependência indica a importância das doações de um empresário, ou de seu setor, para a campanha de um candidato ${ }^{15}$. Por sua vez, a dominância indica em que medida determinada candidatura concentrou em si as doações feitas por um empresário ou seu setor. A dominância mostra, portanto, o predomínio de uma candidatura diante das doações de um empresário ou setor econômico ${ }^{16}$.

Dependência e dominância são indicadores independentes entre si. Quanto mais um candidato depende das doações feitas por um empresário ou setor, e quanto mais as domina, maior a força do vínculo entre doador e recebedor. Neste caso, o doador concentra suas fichas num candidato e esse candidato depende basicamente das fichas daquele doador - doador e candidato estão fortemente unidos um ao outro. Por outro lado, quanto menos um candidato depende das doações de um empresário ou setor, e quanto menos as domina, menor a força do vínculo entre os dois polos. Nesse caso, pode-se supor que doador e recebedor são indiferentes entre si, ou até mesmo adversários um do outro. Pode acontecer, no entanto, de um candidato dominar as doações de um empresário ou setor, porém ser pouco dependente delas. Isso indicará que, por alguma razão, o doador decidiu concentrar suas fichas num candidato, mas que o candidato não depende dessas fichas, podendo contar com outras fontes de receita para sua campanha. Tal cenário pode dar ao recebedor margem de manobra diante do doador. Por fim, pode acontecer também de um candidato amealhar apenas uma pequena parcela das doações de um empresário ou setor e, no entanto, ser fortemente dependente dessas doações para tocar sua campanha. Nesse caso, é o doador que terá margem de manobra ampliada em relação ao recebedor ${ }^{17}$.

15 A fórmula para a mensuração da dependência é: "Total de doações feitas pelo empresário ou setor para determinada candidatura"/"Total de doações recebidas por esta candidatura".

16 A fórmula para a mensuração da dominância é "Total de doações feitas pelo empresário ou setor para determinada candidatura"/"Total de doações feitas pelo empresário ou setor".

17 Para um estudo sobre dependência em relação às doações empresariais nas eleições proporcionais brasileiras, ver Mancuso et al. (2016). Para um estudo sobre dominância nas doações empresariais em eleições proporcionais brasileiras, ver Mancuso e Speck (2015b).

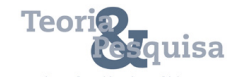


As Tabelas 3 e 4, apresentadas a seguir, mostram o grau de dependência e dominância das candidaturas presidenciais de 2014 em relação às doações feitas pelas empresas dos diferentes setores da economia brasileira.

Quão dependentes das doações eleitorais dos diversos setores da economia brasileira mostraram-se as candidaturas presidenciais de 2014? A Tabela 3 responde esta questão.

Foi semelhante, em termos relativos, o grau de dependência das candidaturas de Dilma Rousseffe de Aécio Neves no que tange às contribuições das três atividades econômicas que se destacaram como principais doadoras na última campanha presidencial, não obstante as diferenças de arrecadação observadas em valores absolutos, pois o volume de contribuições destinado à campanha vencedora foi sistematicamente maior.

De fato, são próximos os percentuais de dependência financeira das campanhas de Dilma e Aécio em relação às doações da indústria de transformação (respectivamente, $41,6 \%$ e 36,2\%), da indústria de construção $(25,7 \%$ e 26,0\%) e do setor de serviços financeiros (12,5\% e 14,5\%). As três atividades responderam por 79,8\% das doações eleitorais para a candidatura Rousseff e 76,7\% das doações para a candidatura Neves. O restante das contribuições empresariais para ambas as candidaturas dividiu-se entre segmentos econômicos diversos, com algum destaque para os ramos do comércio (4,2\%) e da indústria extrativa (4,1\%), no caso de Dilma, e do comércio $(7,1 \%)$ e de atividades administrativas e serviços complementares (3,8\%), no caso de Aécio.

As três maiores atividades doadoras também foram responsáveis por mais da metade das contribuições de campanha para Eduardo Campos/ Marina Silva: indústria de transformação (29,6\%), serviços financeiros (12,4\%) e indústria de construção (11,3\%), totalizando 53,3\%. Neste caso, no entanto, o segundo lugar ficou com o ramo de "outras atividades de serviços", fonte de 13,5\% das doações recebidas pelos candidatos do PSB. As demais contribuições para a candidatura dispersaram-se por segmentos econômicos diversos.

Mesmo as pequenas candidaturas de direita dependeram de forma significativa das contribuições feitas pelas principais atividades doadoras. No caso de Eymael, 66,0\% das doações recebidas vieram dos serviços financeiros e 24,3\% de construtores - nada menos que $90,3 \%$ do total arrecadado pelo candidato. 28,1\% das doações para Pastor Everaldo vieram do setor de construção, ao passo que 14,6\% procederam da indústria de transformação e 14,0\% do setor financeiro, totalizando 56,7\%. 54,6\% das doações 


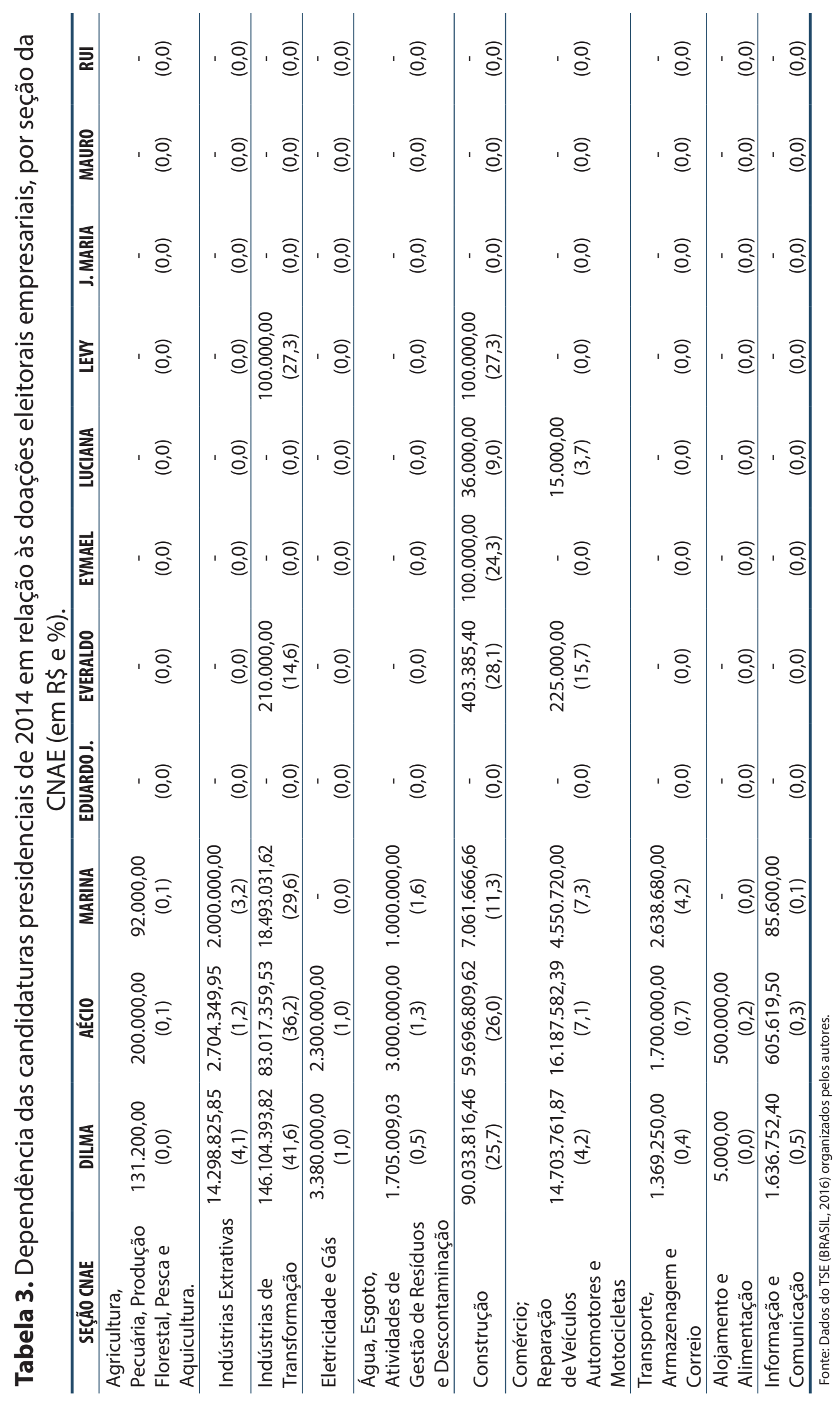




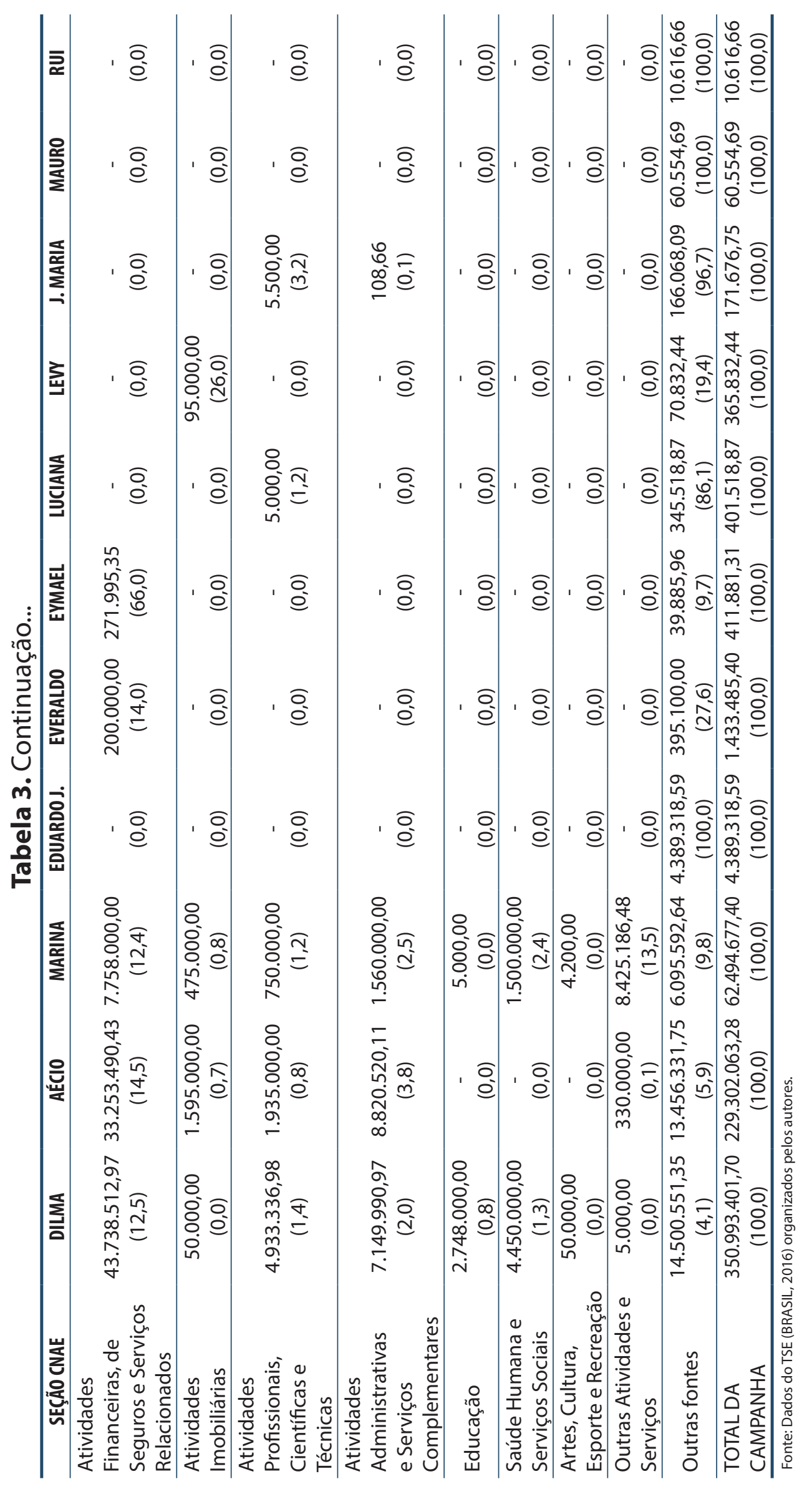




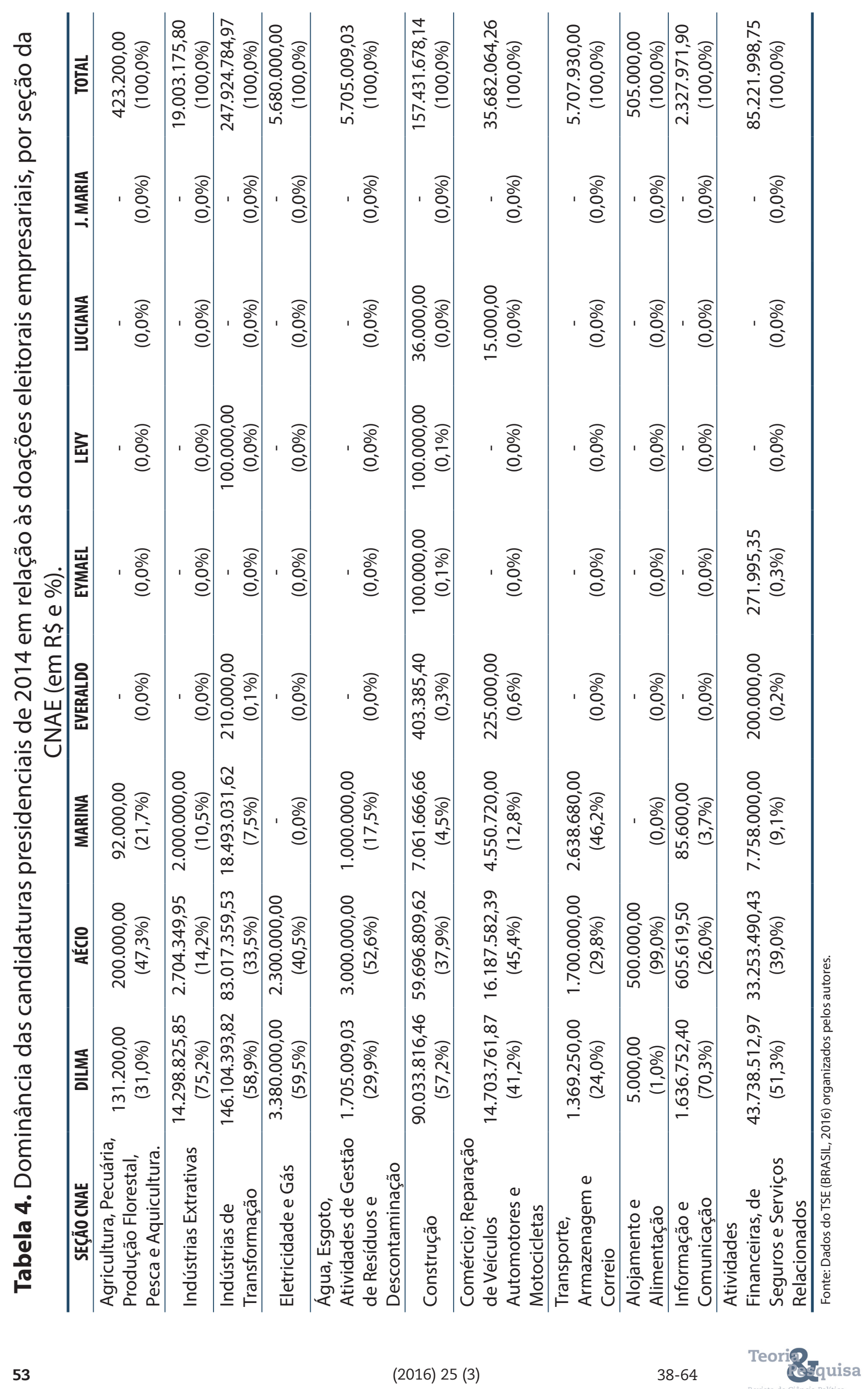




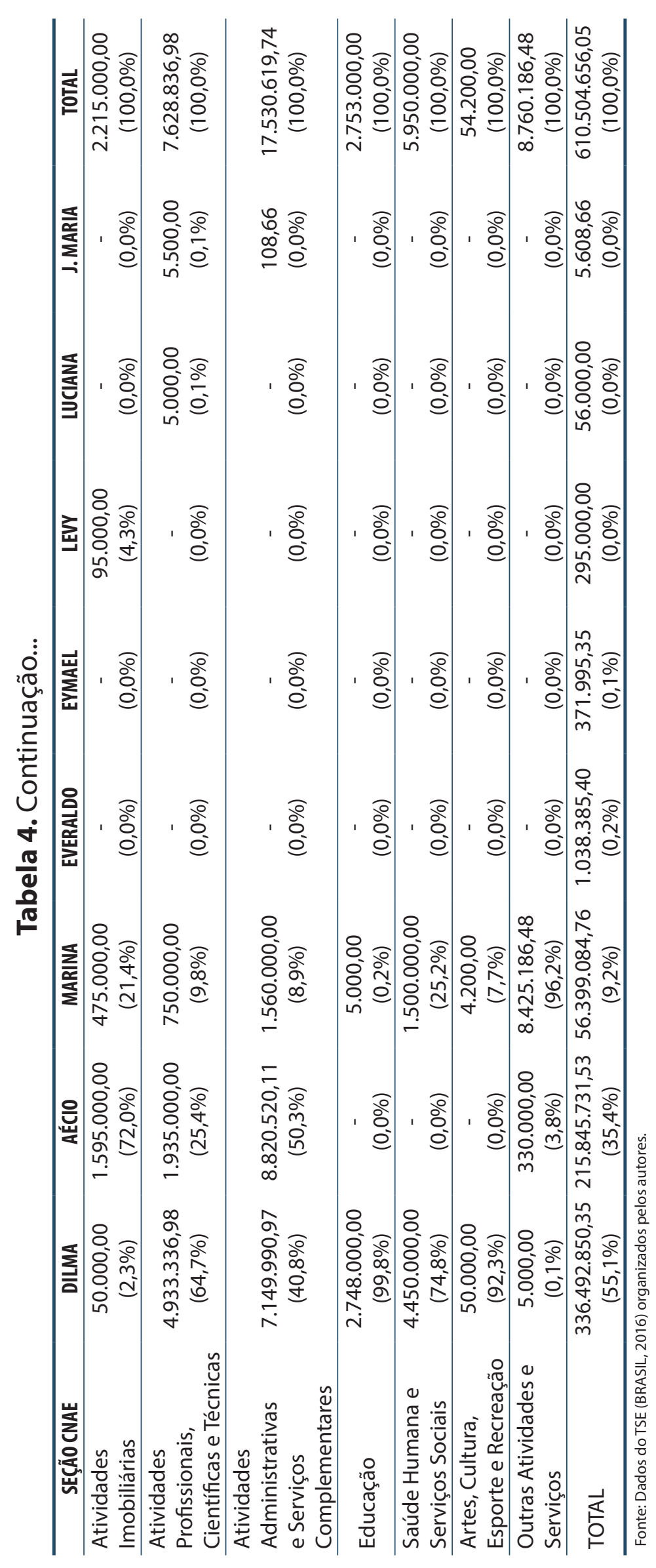


para Levy Fidélix vieram das indústrias de transformação e construção, cada uma delas sendo responsável por metade desse percentual.

Por fim, as pequenas candidaturas de esquerda que receberam alguma doação empresarial mostraram-se pouco dependentes, em termos relativos, das contribuições de quaisquer ramos de atividade econômica.

Os dados da Tabela 3 mostram o quanto cada candidatura dependeu das doações dos diferentes segmentos empresariais brasileiros. A Tabela 4 proporciona outro olhar sobre os mesmos dados, indicando em que grau as diferentes candidaturas dominaram as doações feitas por aqueles segmentos.

Dentre as dezoito seções da CNAE que contribuíram financeiramente para a campanha presidencial de 2014, a candidatura Dilma predominou em dez (ou seja, 55,6\% das seções doadoras). A maior dominância se observou no setor de educação, um setor que fez poucas doações, mas no qual a candidatura vencedora concentrou nada menos que 99,8\% das contribuições. Outro setor cujas doações foram fortemente dominadas por Dilma foi o de "artes, cultura, esporte e recreação", que também contribuiu comparativamente pouco para as campanhas, mas que concentrou na candidatura vencedora 92,3\% de seus recursos. Em seguida, com percentuais de dominância um pouco mais baixos, mas ainda assim significativos, vêm outras cinco seções da CNAE, a saber: indústrias extrativas (75,2\%), saúde humana e serviços sociais (74,8\%), informação e comunicação (70,3\%), atividades profissionais, científicas e técnicas (64,7\%), e eletricidade e gás (59,5\%). Por fim, Dilma Rousseff também prevaleceu nas contribuições eleitorais oferecidas pelos três setores que mais doaram na campanha presidencial de 2014: indústrias de transformação (que teve 58,9\% das doações concentradas na candidata do PT), construção (57,2\%) e atividades financeiras, de seguros e serviços relacionados (51,3\%).

A candidatura de Aécio Neves, do PSDB, predominou nas doações feitas por seis segmentos empresariais (isto é, 33,3\% do total). Os dois setores em que o tucano mais prevaleceu foram setores que fizeram comparativamente poucas doações, quais sejam, alojamento e alimentação (que concentrou em Neves 99,0\% de suas contribuições eleitorais) e atividades imobiliárias (72,0\%). Aécio também recebeu a maioria absoluta das doações procedentes de outros dois ramos empresariais, a saber, "água, esgoto, atividades de gestão de resíduos e descontaminação" (52,6\%) e atividades administrativas e serviços complementares (50,3\%). Em dois casos a candidatura de Aécio Neves também dominou as doações, mas a proporção recebida ficou aquém da maioria absoluta: 
um setor que contribuiu relativamente pouco ("agricultura, pecuária, produção florestal, pesca e aqüicultura", 47,3\%) e outro setor cujas contribuições foram comparativamente mais abundantes ("comércio; reparação de veículos automotores e motocicletas", 45,4\%).

A candidatura do PSB, por sua vez, figurou como o destino preferencial das contribuições de dois setores, o que corresponde a 11,1\% do total de seções doadoras da CNAE. Por um lado, concentrou quase a totalidade das doações realizadas pela seção de "outras atividades de serviços" (96,2\%). Por outro lado, recebeu 46,2\% das doações do segmento de transporte, armazenagem e correio - proporção inferior à maioria absoluta, mas ainda assim suficiente para Ihe garantir a dominância relativa neste caso.

Nenhuma das outras oito candidaturas dominou uma parcela majoritária, ou sequer relevante, das contribuições proporcionadas por algum setor da economia brasileira.

\section{Considerações finais: voltando a pensar no nível macro - rumo ao cartel de partidos ou de volta aos partidos de quadro, de massas e "catch-all"?}

Em síntese, os dados apresentados neste artigo sobre o financiamento empresarial na eleição presidencial brasileira de 2014 permitem concluir que:

(i) o dinheiro dos empresários bancou esta eleição, sendo fonte de 93,9\% dos recursos que a movimentaram;

(ii) o financiamento empresarial foi distribuído de forma muito assimétrica entre as candidaturas, concentrando-se principalmente na campanha vitoriosa de Dilma Rousseff (55,1\% do total), mas sem descuidar da principal campanha de oposição, liderada por Aécio Neves (35,4\%). O dinheiro empresarial ajudou a impulsionar o bom desempenho dessas candidaturas nas pesquisas de opinião e nas urnas, e o bom desempenho dessas candidaturas ajudou a atrair mais dinheiro empresarial para elas. A campanha de Marina Silva, terceira colocada no primeiro turno, recebeu 9,2\% das doações empresariais. O pouco que restou - apenas 0,3\% do total - foi destinado a cinco candidaturas menores, principalmente três ligadas a pequenos partidos de direita (Pastor Everaldo, Eymael e Levy Fidélix);

(iii) embora, em valores absolutos, o financiamento empresarial tenha sido distribuído pelas diferentes candidaturas de modo muito desigual, várias campanhas dependeram 
fortemente deste tipo de financiamento, em termos relativos. Entre as três candidaturas mais votadas, o grau de dependência chegou, respectivamente, a 95,9\%, 94,1\% e 90,2\%. Outras três candidaturas, apresentadas por pequenos partidos de direita, também dependeram substancialmente dos recursos empresariais: Eymael (90,3\%), Levy Fidélix (80,6\%) e Pastor Everaldo (72,4\%). Quatro candidaturas apresentadas por pequenos partidos de esquerda (Luciana Genro, José Maria, Mauro lasi e Rui Pimenta), e uma apresentada por pequeno partido de centro (Eduardo Jorge), em pouco ou nada dependeram do financiamento empresarial;

(iv) as doações empresariais foram fortemente concentradas por companhias ligadas a três setores da economia nacional. A proporção de recursos doados por esses setores não acompanhou sua importância relativa para o VAB de 2014: indústria de transformação (40,6\% das doações e 12,0\% do VAB), indústria da construção (25,8\% das doações e 6,2\% do VAB) e atividades financeiras, de seguros e serviços relacionados (14,0\% das doações e 6,4\% do VAB);

(v) em valores absolutos, Dilma recebeu mais recursos que Aécio destes três setores econômicos: o grau de dominância de Dilma nos três segmentos foi, respectivamente, de 58,9\%, 57,2\% e 51,3\%, ao passo que o de Aécio foi, respectivamente, de 33,5\%, $37,9 \%$ e 39,0\%. No entanto, em termos relativos, foi muito parecido o grau de dependência de ambas as campanhas em relação às contribuições destes setores: no caso de Dilma, 41,6\%, 25,7\% e 12,5\% e, no caso de Aécio, 36,2\%, 26,0\% e 14,5\%. A campanha de Marina, que em valores absolutos recebeu comparativamente pouco dos três setores, deles dependeu para obter mais da metade dos recursos arrecadados (respectivamente, 29,6\%, 11,3\% e 12,4\%), destacando-se ainda, nesse caso, a dependência em relação às doações do setor de "outras atividades de serviços" (13,5\% das doações). As demais candidaturas não se apropriaram de parcela relevante das doações eleitorais feitas por nenhum setor empresarial, embora, no pouco que receberam, as três pequenas candidaturas de direita mencionadas acima tenham dependido, em grande medida, de contribuições realizadas pelos três principais setores doadores.

O que se viu, portanto, na eleição presidencial brasileira de 2014, foi um predomínio incontrastável do dinheiro empresarial, doado sobretudo por empresas ligadas a poucos setores da economia nacional, de forma muito desproporcional à importância desses 
setores para o VAB daquele ano. Em valores absolutos, a divisão deste dinheiro entre as candidaturas foi fortemente assimétrica, em alguma medida sendo afetada por expectativas de desempenho eleitoral e, simultaneamente, afetando-as. Todavia, em termos relativos, todas as candidaturas mais competitivas, e inclusive algumas candidaturas de direita pouco competitivas, foram altamente dependentes do dinheiro empresarial. A exceção ficou por conta de cinco candidaturas pequenas, mormente de esquerda.

Pesquisas futuras poderão contribuir para o acúmulo de conhecimento sobre o assunto de diversas formas, entre elas: (i) expandindo a pesquisa de modo a abarcar e comparar diversas eleições presidenciais e (ii) investigando de forma sistemática, por meio de pesquisas quantitativas e qualitativas, as causas do comportamento doador dos diferentes setores econômicos, bem como das empresas que os compõem.

Nos parágrafos finais deste trabalho, nos permitiremos passar brevemente da esfera da análise para a esfera da conjectura. Em setembro de 2015, quase um ano após as eleições presidenciais tratadas neste artigo, o plenário do STF decidiu proibir o financiamento eleitoral empresarial. Pelo exposto até aqui, é fácil perceber que esta decisão subverteu completamente os fundamentos da competição eleitoral no país. Portanto, as questões cruciais que se colocam são: de agora em diante, que rumo tomará o financiamento das campanhas eleitorais no Brasil? E como este rumo afetará o comportamento dos partidos e de suas candidaturas presidenciais?

Basicamente, duas opções estão sobre a mesa: ou a proibição atual será mantida, ou alguma forma de financiamento eleitoral empresarial será reinstituída (via Congresso Nacional ou via revisão da decisão do STF) ${ }^{18}$. Qualquer que seja a opção que venha a prevalecer, ela provavelmente deflagrará múltiplas pressões contraditórias sobre partidos e candidaturas.

Caso a proibição atual seja mantida, é provável que se procure combinar a redução dos custos de campanha com a busca de novas fontes de recursos ${ }^{19}$. Uma primeira

\footnotetext{
18 Reportagem publicada pelo jornal "O Estado de São Paulo" no dia 19 de setembro de 2016 assegurou que deputados e senadores articulam a volta do financiamento eleitoral empresarial (GADELHA, 2016). Por sua vez, o ministro do STF Gilmar Mendes, atual presidente do Tribunal Superior Eleitoral (TSE), que na decisão de setembro de 2015 votou contra a proibição do financiamento empresarial, tem feito frequentes declarações públicas em defesa deste tipo de financiamento. Ver, por exemplo, essas três reportagens: Macedo e Affonso (2016), Lindner (2016) e Presidente do TSE (FOLHA DE SÃO PAULO, 2016).
}

19 Proposições legislativas aprovadas recentemente pelo Congresso Nacional visaram à redução de custos de campanha, tais como a Lei No.11.300/06 (que proibiu outdoors, espetáculos, showmícios, apresentação de artistas em comícios e distribuição de brindes), a Lei No. 12.891/13 (que instituiu teto para gastos com veículos automotores e com a alimentação do pessoal de campanha, e estabelecimento de dimensões máximas para adesivos) e a Lei No. 13.165/15 (que estabeleceu limite máximo para os gastos de campanha e reduziu o período da campanha eleitoral, o período do horário eleitoral gratuito no rádio e na TV e o número máximo de candidatos às eleições proporcionais em municípios e estados de maior porte). 
possibilidade é que haja pressão para a passagem de uma situação de dependência em relação ao grande empresariado, para uma situação de dependência em relação ao estado. Os partidos brasileiros poderão seguir, então, a tendência de "cartelização"já apontada por Katz e Mair $(1995,1996,2009,2012)$ nos partidos europeus²0 . Essa pressão à cartelização tende a se exercer sobre todos os partidos, mas partidos grandes e pequenos tenderão a se colocar em lados opostos no que se refere à destinação dos recursos estatais. Os primeiros defenderão a concentração dos recursos estatais em si mesmos, para "combater a fragmentação partidária", e os segundos defenderão maior dispersão dos recursos estatais entre todos os partidos, para "fortalecer a competição política".

A segunda possibilidade é que aumente o incentivo para a busca de recursos individuais. Nesse cenário, ainda na terminologia de Katz e Mair (2009, p. 756), a militância ("party on the ground") pode retomar importância vis-à-vis os ocupantes de cargos públicos ("party in public office") e a burocracia partidária ("party in central office"), ao menos no momento eleitoral. Isso pode levar as siglas e as candidaturas a reforçarem seu perfil ideológico e a ligação com grupos de interesses, levando-as não na direção da cartelização, mas de volta à direção dos partidos de massa (DUVERGER, 1970) com clientelas politicamente bem definidas em torno de ideologias e interesses ${ }^{21}$. A busca por recursos individuais também pode levar os partidos e as candidaturas a dependerem, de forma mais intensa, das contribuições de indivíduos ricos. Assim, a influência do dinheiro sobre a disputa eleitoral pode ressurgir sob nova roupagem. A busca por recursos individuais pode levar ainda ao lançamento de candidatos ricos, que possam custear suas campanhas com recursos próprios²2. De um modo ou de outro, em função da busca por recursos individuais, o retorno a alguma forma de partidos de "quadros" não pode ser excluído (DUVERGER, 1970).

20 Apesar da enorme crise fiscal enfrentada pelo Brasil em 2015, o volume de recursos do orçamento destinado ao fundo partidário naquele ano foi de $\mathrm{R} \$ 867,5$ milhões de reais, o triplo do que destinado em 2014 (DELLA COLETTA, 2015). Em 2016, com a continuidade da crise, o fundo partidário sofreu pequena redução de 5,6\%, indo para R\$ 819 milhões de reais (G1 - O GLOBO, 2016). Este valor foi mantido no orçamento de 2017 (JUNGBLUT, 2016). Todavia, os partidos continuam buscando aumentar o volume de recursos públicos destinados a si mesmos. Segundo esta reportagem do portal de notícias "UOL", Gilberto Kassab, atual ministro da ciência, tecnologia, inovações e comunicações, propôs em outubro de 2016 que o fundo partidário fosse a R\$2,9 bilhões de reais, o que significaria um aumento de nada menos que 254\% (SOUZA, 2016).

$\mathbf{2 1}$ Há candidaturas que apostam em campanhas de arrecadação de recursos junto a militantes e simpatizantes. O avanço da tecnologia de pagamentos pela internet facilita campanhas desse tipo. Além de dinheiro, as candidaturas também podem incentivar militantes e simpatizantes a doar tempo para atividades de campanha, tais como reuniões de definição de estratégia, panfletagem nas ruas, atuação junto às redes sociais, etc.

22 A legislação atual (Lei No 13.165/15) estabelece tetos para os gastos de campanha e permite que os candidatos façam autodoações até este teto. Há evidências de que esse modelo favoreceu candidatos ricos (TAQUARI et al., 2016). 
A terceira possibilidade é o recurso crescente, via "caixa dois", a formas ilegais de financiamento eleitoral, com o erário público sendo usado como moeda de troca entre partidos e financiadores ${ }^{23}$. Nesse caso, terminaríamos apenas com "mais do mesmo", pois o noticiário político nacional dá provas fartas de que o "caixa dois" existiu mesmo em um contexto em que as doações empresariais eram oficialmente permitidas.

A nosso ver, essas diferentes possibilidades coexistem e diferentes partidos recorrerão a elas em diferentes medidas, em função de variáveis como porte, grau de competitividade eleitoral e perfil político mais ideológico ou pragmático.

Por outro lado, caso o financiamento eleitoral empresarial seja reinstituído, seu efeito sobre partidos e candidaturas dependerá das condições em que for admitido. Se o teto para as contribuições empresariais for permissivo como era antes de setembro de 2015 (pelo menos para grandes empresas), então é provável que ressurja o cenário apresentado nesse texto: ampla dependência em relação aos recursos empresariais, tanto por parte das candidaturas "catch all" (Kirchheimer, 2012) mais competitivas, que dominarão grande proporção dos recursos disponibilizados, quanto por parte de candidaturas menos competitivas, porém pouco refratárias ao recebimento deste tipo de recursos. Entretanto, se o teto para as doações empresariais for suficientemente baixo para não permitir que as campanhas dependam significativamente das contribuições de um pequeno punhado de grandes doadores, então os partidos e suas candidaturas precisarão mudar a estratégia de arrecadação que adotaram até às eleições de 2014, buscando amealhar doações menores de um número bem maior de empresários. Num cenário como esse, a coexistência de pressões contraditórias por cartelização, revitalização da militância, busca de recursos individuais e apelo ao "caixa dois" não pode ser excluída²4.

\section{Referências}

BRASIL. Lei 9.504, de 30 de setembro de 1997. Estabelece normas para as eleições. Diário Oficial [da] República Federativa do Brasil, Brasília, DF, 1 out. 1997. Disponível em: <http://www. planalto.gov.br/ccivil_03/leis/L9504.htm>. Acesso em: 11 dez. 2016.

23 O senador piauiense Ciro Nogueira, presidente nacional do Partido Progressista, declarou que as eleições municipais de 2016 seriam a eleição do "caixa dois" (BRITO; BRAMATTI, 2016).

24 Para excelente reflexão sobre financiamento eleitoral no Brasil à luz da tipologia de partidos de Duverger, Kirchheimer e Katz e Mair, ver Krause, Rebello e Silva (2015). 
BRASIL. Lei 11.300, de 10 de maio de 2006. Dispõe sobre propaganda, financiamento e prestação de contas das despesas com campanhas eleitorais, alterando a Lei no 9.504, de 30 de setembro de 1997. Diário Oficial [da] República Federativa do Brasil, Brasília, DF, 11 maio 2006. Disponível em: <http://www.planalto.gov.br/ccivil_03/_Ato2004-2006/2006/Lei/L11300. htm>. Acesso em: 11 dez. 2016.

BRASIL. Lei 12.034, de 29 de setembro de 2009. Altera as Leis nos 9.096, de 19 de setembro de 1995 - Lei dos Partidos Políticos, 9.504, de 30 de setembro de 1997, que estabelece normas para as eleições, e 4.737, de 15 de julho de 1965 - Código Eleitoral. Diário Oficial [da] República Federativa do Brasil, Brasília, DF, 30 set. 2009. Disponível em: <http://www. planalto.gov.br/ccivil_03/_ato2007-2010/2009/lei/l12034.htm>. Acesso em: 11 dez. 2016.

BRASIL. Lei 12.891, de 11 de dezembro de 2013. Altera as Leis nos 4.737, de 15 de julho de 1965, 9.096, de 19 de setembro de 1995, e 9.504, de 30 de setembro de 1997, para diminuir o custo das campanhas eleitorais, e revoga dispositivos das Leis nos 4.737, de 15 de julho de 1965, e 9.504, de 30 de setembro de 1997. Diário Oficial [da] República Federativa do Brasil, Brasília, DF, 12 dez. 2013. Disponível em: <http://www.planalto.gov.br/ccivil_03/_Ato20112014/2013/Lei/L12891.htm>. Acesso em: 11 dez. 2016.

BRASIL. Tribunal Superior Eleitoral - TSE. Prestação de contas 2014. Brasília, 2016. Disponível em: <http://www.tse.jus.br/eleicoes/estatisticas/repositorio-de-dados-eleitorais>. Acesso em: 11 dez. 2016.

BRITO, R.; BRAMATTI, D. Não tenho nenhuma dúvida de que esta será a eleição do caixa 2, diz presidente do PP. O Estado de S. Paulo, São Paulo, 1 ago. 2016. Disponível em: < http://politica. estadao.com.br/noticias/geral,nao-tenho-nenhuma-duvida-de-que-esta-sera-a-eleicaodo-caixa-2-diz-presidente-do-pp,10000066233>. Acesso em: 20 set. 2016.

DELLA COLETTA, R. Parlamentares triplicam Fundo Partidário. O Estado de S. Paulo, São Paulo, 18 mar. 2015. Disponível em: <http://politica.estadao.com.br/noticias/geral,parlamentarestriplicam-fundo-partidario-imp-,1653000>. Acesso em: 20 set. 2016.

DUVERGER, M. Os partidos políticos. Rio de Janeiro: Zahar, 1970.

FIGUEIREDO FILHO, D. O elo corporativo? Grupos de interesse, financiamento de campanha e regulação eleitoral. 2009. 100 f. Dissertação (Mestrado em Ciência Política)-Programa de Pós-graduação em Ciência Política, Universidade Federal de Pernambuco, Recife, 2009.

FOLHA DE S. PAULO. Presidente doTSE, Gilmar Mendes vai estimular Congresso a rever sistema eleitoral do Brasil. São Paulo, ,11 dez. 2016. Disponível em: <http://painel.blogfolha.uol. com.br/2017/01/01/presidente-do-tse-gilmar-mendes-vai-estimular-congresso-a-reversistema-eleitoral-do-brasil/>. Acesso em: 11 dez. 2016.

G1 - O GLOBO. Orçamento de 2016 reserva R\$ 819 mi para fundo de partidos. Brasília, 15 jan. 2016. Disponível em: <http://g1.globo.com/politica/noticia/2016/01/orcamento-de-2016-repassar-819-mi-para-fundo-de-partidos.html>. Acesso em: 20 set. 2016. 
GADELHA, I. Parlamentares articulam volta de doação de empresa. O Estado de S. Paulo, São Paulo, 19 set. 2016. Disponível em: <http://politica.estadao.com.br/noticias/geral,parlamentaresarticulam-volta-de-doacao-de-empresa,10000076824>. Acesso em: 20 set. 2016.

HOROCHOVSKI, R. et al. Redes de partidos políticos tecidas por financiadores: um estudo das eleições de 2010 no Brasil. Teoria \& Sociedade, v. 23, n. 2, p. 49-78, 2015.

HOROCHOVSKI, R. et al. Estruturas de poder nas redes de financiamento político nas eleições de 2010 no Brasil. Opinião Pública, v. 22, p. 28-55, 2016.

INSTITUTO BRASILEIRO DE GEOGRAFIA E ESTATÍSTICA - IBGE. Sistema de contas nacionais: Brasil: 2010-2014. Rio de Janeiro, 2016.

INTERNATIONAL INSTITUTE FOR DEMOCRACY AND ELECTORAL ASSISTANCE - INTERNATIONAL IDEA. Political Finance Database. Stockholm, 2016. Disponível em: <http://www.oldsite.idea. int/political-finance/index.cfm>. Acesso em: 11 dez. 2016.

JUNGBLUT, C. Fundo Partidário será de R\$ 819 milhões em 2017, o mesmo de 2016, O Globo, Rio de Janeiro, 16 dez. 2016. Disponível em: <http://oglobo.globo.com/brasil/fundo-partidariosera-de-819-milhoes-em-2017-mesmo-de-2016-20656120>. Acesso em: 11 dez. 2016.

KATZ, R.; MAIR, P. Changing models of party organization and party democracy: the emergence of the cartel party. Party Politics, v. 1, n. 1, p. 5-28, 1995.

KATZ, R.; MAIR, P. Cadre, catch-all or cartel? A rejoinder. Party Politics, v. 2, n. 4, p. 525-534, 1996.

KATZ, R.; MAIR, P. The cartel party thesis: a restatement. Perspectives on Politics, v. 7, n. 4, p. 753$766,2009$.

KATZ, R.; MAIR, P. Parties, interest groups and cartels: a comment. Party Politics, v. 18, n. 1, p. 107-111, 2012.

KIRCHHEIMER, O. A transformação dos sistemas partidários da Europa Ocidental. Revista Brasileira de Ciência Política, n. 7, p. 349-385, 2012.

KRAUSE, S.; REBELLO, M.; SILVA, J. O perfil do financiamento dos partidos brasileiros (20062012): autores, objetivos, êxito e fracasso (1998-2010). Revista Brasileira de Ciência Política, n. 16, p. 247-272, 2015.

LEMOS, L.; MARCELINO, D.; PEDERIVA, J. H. Porque dinheiro importa: a dinâmica das contribuições eleitorais para o Congresso Nacional em 2002 e 2006. Opinião Pública, v. 16, n. 2, 2010.

LINDNER, J. Gilmar Mendes diz que fim de financiamento privado foi um 'salto no escuro'Para o presidente do TSE, eleição municipal deste ano é um 'experimento institucional' e em novembro deverá haver uma discussão sobre uma reforma no sistema eleitoral. O Estado de S. Paulo, 25 jul. 2016. Disponível em: <http://politica.estadao.com.br/noticias/eleicoes, gilmarmendes-diz-que-fim-de-financiamento-privado-foi-um-salto-no-escuro, 10000064841>. Acesso em: 20 set. 2016.

MACEDO, F.; AFFONSO, J.'Enormes chances de fraudes', diz Gilmar sobre eleições. O Estado de S. Paulo, São Paulo, 15 maio 2016. Disponível em: <http://politica.estadao.com.br/blogs/

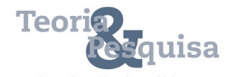


fausto-macedo/enormes-chances-de-fraudes-diz-gilmar-sobre-eleicoes16/.Acesso em: 20 set. 2016.

MANCUSO, W. Investimento eleitoral no Brasil: balanço da literatura (2001-2012) e agenda de pesquisa.Revista de Sociologia e Politica, v. 23, n. 54, p. 155-183, 2015.

MANCUSO, W.; SPECK, B. Financiamento empresarial na eleição para deputado dederal (20022010): determinantes e consequências. Teoria e Sociedade, v. 23, n. 2, p. 103-125, 2015a.

MANCUSO, W:; SPECK, B. Os preferidos das empresas: um estudo de determinantes do financiamento eleitoral empresarial. In: COSTA, P. R. N.; PONT, J (Org.). Empresários, desenvolvimento, cultura e democracia. Curitiba: Editora da UFPR, 2015b. p. 185-195.

MANCUSO, W. et al. Corporate dependence in Brazil's 2010 elections for federal deputy.Brazilian Political Science Review, v. 10, n. 3, p. 1-22, 2016.

MARCELINO, D. Sobre dinheiro e eleições: um estudo dos gastos de campanha para o Congresso Nacional em 2002 e 2006. 2010. 123 f. Dissertação (Mestrado em Ciências Sociais)-Centro de Pesquisa e Pós-graduação sobre as Américas, Universidade de Brasília, Brasília, 2010.

MARCELINO, D. Do public opinion polls matter for campaign contributors? Evidence from Brazil. In: CONFERÊNCIA IPSA-ECPR"Whatever Happened to North-South?", 2011, São Paulo, Anais... São Paulo: International Political Science Association - Eudopean Consortium for Political Research (IPSA-EPCR), 2011. p. 1-13.

MCMENAMIN, I. The four logics of business, money, and political parties, In: MCGRATH, C. (Org.). Interest groups and lobbying in the United States and comparative perspectives. Lewiston: The Edwin Mellen Press, 2009. p. 207-223.

MCMENAMIN, I. If money talks, what does it say?: Varieties of capitalism and business financing of parties. World Politics, v. 64, n. 1, 2012.

PEIXOTO, V. Eleições e financiamento de campanhas no Brasil. 2010. 175 f. Tese (Doutorado em Ciência Política)-Instituto Universitário de Pesquisas do Rio de Janeiro, Rio de Janeiro, 2010.

SAMUELS, D. Money, elections, and democracy in Brazil. Latin American Politics and Society, v. 43, n. 2, p. 27-48, 2001.

SAMUELS, D. Pork barreling is not credit claiming or advertising: campaign finance and the source of the personal vote in Brazil.The Journal of Politics, v. 64, n. 3, p. 845-863, 2002.

SILVA, B.; GONÇALVES, R. É financiado porque é competitivo ou é competitivo porque é financiado? Intenção de voto e receitas eleitorais de candidatos ao Senado em 2014. In: ENCONTRO ANUAL DA ASSOCIAÇÃO NACIONAL DE PÓS-GRADUAÇÃO E PESQUISA EM CIÊNCIAS SOCIAIS, 40., 2016, Caxambu. Anais... São Paulo: ANPOCS, 2016. p. 1- 24.

SOUZA, J. Câmara discute novo fundo público de financiamento das eleições: R\$2,9 bi. Blog do Josias, 06 out. 2016. Disponível em: <http://josiasdesouza.blogosfera.uol.com.br/2016/10/06/ camara-discute-novo-fundo-publico-de-financiamento-das-eleicoes-r-29-bi/>. Acesso em: 28 dez. 2016. 
SPECK, B. Objetivos e estratégias do setor privado no financiamento das campanhas eleitorais: um modelo de análise baseado em dados da campanha eleitoral no Brasil em 2010. In: CONFERÊNCIA IPSA-ECPR“"Whatever Happenedto North-South?", 2011, São Paulo, Anais... São Paulo: International Political Science Association-European Consortium for PoliticalResearch (IPSA-EPCR), 2011. p. 1-20.

TAQUARI et al. Nova regra de doação favorece candidatos ricos. Valor Econômico, São Paulo, 29 jun. 2016. Disponível em: <http://www.valor.com.br/politica/4617911/nova-regra-deautodoacao-favorece-candidatos-ricos>. Acesso em: 20 set. 2016.

TAROUCO, G.; MADEIRA, R. Partidos, programas e o debate sobre esquerda e direita no Brasil. Revista de Sociologia e Política, Curitiba, v. 21, n. 45, p. 149-165, 2013.

Recebido: 08 set., 2016 Aceito: 11 dez., 2016 